\title{
Nadir Görülen Bir Akut Karın Olgusu: İdiopatik Omental İnfarkt
}

\author{
A Rare Case of Acute Abdomen: İdiopathic Omental İnfarction
}

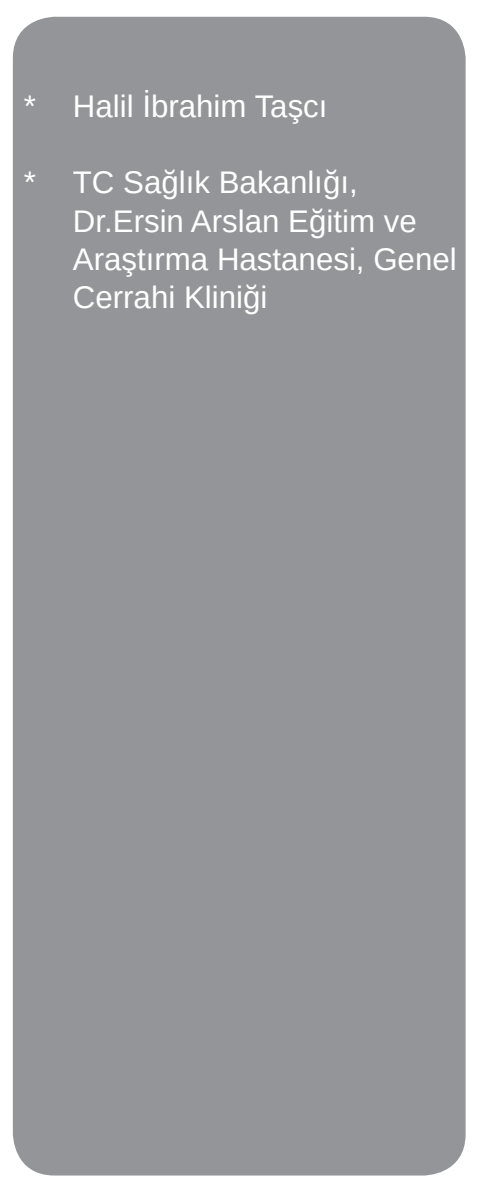

Yazışma Adresi:

Halil İbrahim Taşcı

TC Sağlık Bakanlığı,

Dr. Ersin Arslan Eğitim ve

Araştırma Hastanesi,

Genel Cerrahi Kliniği,

GAZIANTEP

E-mail: okcu1@mynet.com

Telefon: 05054810445

\section{Öz}

Omental infarkt büyük omentumun kan akımında azalma sonucu ortaya çıkan nadir bir durumdur. Çoğunlukla altta yatan başka bir patolojiye ikincil ortaya çıksa da herhangi bir sebebe bağlı olmaksızın da görülebilmektedir. Bilinen herhangi bir ek hastalığı ya da geçirilmiş cerrahi öyküsü olmayan 65 yaşında bayan hasta iki gündür olan ve giderek artan, sağ alt kadranda daha belirgin ağrı şikayeti ile başvurdu. Karın ağrısına eşlik eden bulantı, kusma, iştahsızlık, ateş gibi başka bir şikayeti yoktu. Yapılan tahlil, tetkik ve muayene bulguları neticesinde hasta idiopatik omental infarkt olarak değerlendirildi. Konservatif olarak takip edilen hasta sorunsuz şekilde taburcu edildi. İdiopatik omental infarkt genelde kendi kendini sınırlayabilen, nadir bir akut karın ağrısı sebebidir. Her ne kadar radyolojik bulguları belirgin olmayan, klinik gidişatı kötü olanlarda cerrahi müdahale zorunlu olsa da tanıda şüphe olmayan hastalarda konservatif tedavi yöntemleri ile gereksiz cerrahi ve anestezi riskleri önlenebilmektedir.

Anahtar Kelimeler: Akut karın, konservatif tedavi, omental infarkt.

\begin{abstract}
Omental infarction is a rare condition caused by the decrease in blood flow in the greater omentum. Although it is mostly seen secondarily to another underlying pathology, it can also emerge independent of any other reason. A 65-year-old female patient, who had no known comorbidity or previous history of surgery, presented with complaints of increasing pain for the last two days which was more pronounced in the right lower quadrant. The patient did not have other complaints like nausea, vomiting, lack of appetite, or fever accompanying abdominal pain. The patient was diagnosed with idiopathic omental infarction as shown by the results of tests, studies, and examinations conducted. The patient was treated conservatively and was discharged without any problems. Idiopathic omental infarction is a rare cause of acute abdomen which can generally limit itself. Although surgical intervention is necessary in cases with unspecified radiological results and bad clinical prognoses, unnecessary surgical procedures and anesthetic risks can be prevented by conservative treatment methods in patients with definitive diagnoses.
\end{abstract}

Keywords: Acute abdomen, conservative treatment, omental infarction. 


\section{Giriş}

Omental infarkt büyük omentumun kan akımında azalma sonucu ortaya çıkan nadir bir durumdur (1). Çoğunlukla altta yatan başka bir patolojiye ikincil ortaya çıksa da herhangi bir sebebe bağlı olmaksızın da görülebilmektedir. Önceki yıllarda tanısal güçlükler sebebi ile idiopatik omental infarkt her ne kadar nadir görülen bir durum olsa da radyolojik yöntemlerdeki gelişmeler sayesinde tanı konulması kolaylaşmış, böylelikle radyoloji ve genel cerrahi literatüründe daha sık yer alır hale gelmiştir $(2,3)$.

Daha çok sağ tarafı etkilemekte ve akut apandisit, akut kolesistit, divertikülit, renal kolik gibi durumların ayırıcı tanısında yer almaktadır(1). Önceki yıllarda tanı büyük çoğunlukla başka nedenlerle yapılan cerrahi esnasında rastlantısal olarak konulmaktaydı. Günümüzde cerrahi işlem öncesi radyolojik olarak tanısının konulabiliyor olması tedavide ameliyatsız takibi gündeme getirmiştir (4).

Bu çalışma ile radyolojik olarak tanısı konulan, cerrahi müdahaleye gerek kalmaksızın başarılı şekilde tedavi edilen idiopatik omental infarkt olgusu sunulmuş ve literatürün gözden geçirilmesi amaçlanmıştır.

\section{Olgu}

Bilinen herhangi bir ek hastalığı ya da geçirilmiş cerrahi öyküsü olmayan 65 yaşında bayan hasta iki gündür olan ve giderek artan, sağ alt kadranda daha belirgin ağrı şikayeti ile başvurdu. Karın ağrısına eşlik eden bulantı, kusma, iştahsızık, ateş gibi başka bir şikayeti yoktu. Hastanın vücut kitle indeksi normal sınırlardaydı. Yapılan karın muayenesinde bağırsak sesleri normaldi. Sağ alt kadranda hassasiyet olmasına rağmen rebound, istemsiz defans gibi diğer peritonit bulguları yoktu. Beyaz küre 6700/uL, CRP:3mg/L olarak saptandı.

Ultrasonografide gaz superpozisyonu nedeni ile belirgin bir patoloji saptanamaması üzerine hastaya yapılan bilgisayarlı karın tomografisinde sağ alt kadranda çekum komşuluğunda omentumda yaygın dansite artışı, çizgisel dansiteler içeren, kitle etkisine yol açan lezyon ve bu lezyon komşuluğunda peritoneal serbest sıvı izlendi(Şekil 1a-1d). Yapılan tahlii, tetkik ve muayene bulguları neticesinde hasta idiopatik omental infarkt olarak değerlendirildi. Öncelikle semptomatik analjezik tedaviyle medikal takibi planlandı. Üç günlük takibi sonrasında şikayetleri düzelen hasta sorunsuz şekilde taburcu edildi. 4 ay boyunca yapılan düzenli kontrolleri esnasında yapılan fizik muayene, görüntüleme ve laboratuvar tetkiklerinde herhangi bir komplikasyona rastlanmadı.

\section{Tartışma}

Omental infarkt akut karın ağrısının nadir görülen; fakat önemli sebeplerinden birisidir. İlk defa 1896 yılında Bush tarafından tanımlanmıştır (5). Akut karın nedeni ile laparotomi yapılan hastaların \%0.1'inde omental infarkt saptanmaktadır (6). En sık dördüncü-beşinci dekadda görülmekle beraber her yaș grubundan vakalar olabilmektedir. Erkekleri kadınlara göre daha çok etkilemektedir. Obezite, geçirilmiş travma ve cerrahi öyküsü, beslenme sonrası vaskuler konjesyon, karın içi basınçta ani artış, herniler, tümör, kist ya da lokalize inflamatuar hadiseler, hiperkoagülabilite gibi altta yatan çok sayıda sebebe bağlı olabileceği gibi daha nadiren idiopatik omental infarkt olarak da ortaya çıkabilmektedir $(7,8)$. Sunduğumuz hastanın da omental enfarkta sebep olabilecek herhangi bir ek hastalığı ya da geçirilmiş cerrahi hikayesi yoktu. Bu yüzden primer omental infarkt olarak değerlendirildi. Damar yapısındaki anatomik varyasyonlar, staz veya tromboza sebep olabilecek venöz malformasyonlar, aşırı ağır yemek sonrası ortaya çıkan venöz konjesyona bağlı gelişebileceği gibi teoriler ortaya atılsa da idiopatik omental infarktın sebebi tam olarak bilinmemektedir (9).

Hastalarda klinik bulgular spesifik değildir. Tutulumun olduğu bölgeye göre şikayetler farklılık gösterebilmektedir. Daha çok sağ alt kadranı etkilediği için akut apandisiti taklit eden semptomları vardır. Hastalar genelde akut ya da subakut başlangıçlı, bulantı-kusma, iştahsızlık ya da ishal gibi gastrointestinal şikayetlerin eşlik etmediği karın ağrısı şikayeti ile başvururlar (1). Ateş genellikle ağrıya eşlik etmez ya da hafif artmış olabilir. Beyaz küre ve C-reaktif protein değerleri normal sınırlarda olabileceği gibi hafif yükselme de saptanabilir (1). Bununla beraber omental infarktın apandisit ya da kolesistit gibi diğer cerrahi patolojilerden klinik olarak ayırt edilmesi zordur (4). Bizim hastamızın da karın ağrısı dışında bulantı-kusma, ateş, iştahsızlık gibi ek bir şikayeti yoktu. Fizik muayenesinde de sağ alt kadranda hassasiyet dışında bir bulgu saptanmadı. 
Radyolojik yöntemler hasta için uygun tedavi yöntemini belirlemede önemli rol oynamaktadırlar. Ultrasonografi ve bilgisayarlı tomografi bulguları oldukça tipiktir. Ultrasonografide hiperekoik solid kitle lezyonu şeklinde görülürken bilgisayarlı tomografide ise yoğunluğu yağ dokusuna göre yüksek, heterojen, ovoid, etrafında visseral peritonun oluşturduğu hiperdens halka görünümü olan kitle lezyonu olarak tarif edilmektedir (10). Omental infarkt vakalarının yarısına yakınında bu lezyon komşuluğunda peritoneal serbest sıvı saptanabilmektedir (4). Sunulan olgunun radyolojik tanısında da bilgisayarlı tomografi kullanılmıştır.

Tedavide medikal takip ya da cerrahi seçeneklerini destekleyen iki farklı görüş vardır. Son yıllarda bilgisayarlı tomografi ile omental patolojinin doğru olarak tanınabilmesi konservatif tedaviyi uygulanabilir bir seçenek haline getirmiştir (11). Bu yaklaşımda ilk etapta optimal Sıvı yönetimi ile analjezik ve anti-inflamatuar ilaç kullanımı önerilmektedir. Konservatif tedavi yöntemini destekleyenlerin genel fikir birliği omental enfarktın kendi kendisini sınırlayan bir patoloji olduğu yönündedir ve bu tezleri de hastalara yapılan uzun dönem tomografi takipleri ile desteklenmektedir (11). Bu şekilde cerrahi müdahale sonucu ortaya çıkabilecek anestezi ve cerrahi riskler de ortadan kaldırılmaktadır. Cerrahi müdahale önerenler ise bu şekilde hastanın şikayetlerinin daha erken kontrol altına alınabileceği ve daha erken taburculuğunun sağlanabileceğini düşünmektedirler. Ayrıca patolojik omentum dokusunun çıkarılmasının, teorik olarak omental infarkta ikincil gelişebilecek apse intimalini de düşüreceğini öne sürmektedirler (12). Fakat yapılan bazı çalışmalar göstermiştir ki konservatif olarak takip edilmiş hastaların hiç birisinde ilerleyen dönemde herhangi bir komplikasyonla karşılaşılmamıştır (4). Cerrahi müdahale planlanan hastalarda laparoskopik yöntemler hem tanısal hem de tedavi açısından düşük morbidite ile uygulanabilir olmasından dolayı tercih sebebidir (13). Hastamızın klinik seyrinin rahat olması, laboratuar bulgularının normal sınırlarda seyretmesi, tanıda herhangi bir şüphe olmaması ve ileri yaşı da göz önüne alınarak konservatif takibi uygun görüldü. Sorunsuz şekilde taburcu edilen hastanın takipleri esnasında da herhangi bir komplikasyon gelişmemiştir.

İdiopatik omental infarkt genelde kendi kendini sınırlayabilen, nadir bir akut karın ağrısı sebebidir. Her ne kadar radyolojik bulguları belirgin olmayan, klinik gidişatı kötü olanlarda cerrahi müdahale zorunlu olsa da tanıda şüphe olmayan hastalarda konservatif te- davi yöntemleri ile gereksiz cerrahi ve anestezi riskleri önlenebilmektedir.

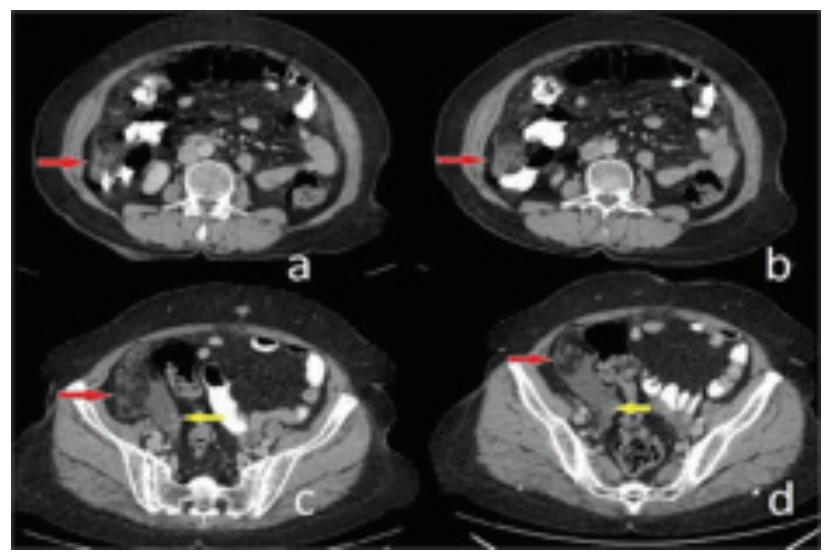

Şekil 1. Omental enfarktın farklı kesitlerde tomografik görünümü( kırmızı ok: omentumda yaygın dansite artışı, çizgisel dansiteler içeren, kitle etkisine yol açan lezyonunun görünümü, sarı ok: lezyon komşuluğundaki serbest sıvının görünümü).

\section{Çıkar Çakışması Beyanı}

Yazar bu yazının hazırlanması ve yayınlanması aşamasında herhangi bir çıkar çakışması olmadığını beyan etmiştir.

\section{Finansman}

Yazar bu yazının araştırma ve yazarlık sürecinde herhangi bir finansal destek almadığını beyan etmiştir.

\section{Kaynaklar}

1. Battaglia L, Belli F, Vannelli A, Bonfanti G, Gallino G, Poiasina E et al. Simultaneous idiopathic segmental infarction of the great omentum and acute appendicitis: a rare association. World J Emerg Surg. 2008 Oct 29; 3: 30.

2. Park TU, Oh JH, Chang IT, Lee SJ, Kim SE, Kim CW et al. Omental infarction: case series and review of the literature. J Emerg Med. 2012 Feb; 42 (2): 149-54.

3. Goti F, Hollmann R, Stieger R, Lange J. Idiopathic segmental infarction of the greater omentum successfully treated by laparoscopy: report of case. Surg Today. 2000; 30 (5): 451-3.

4. Soobrah R, Badran M, Smith SG. Conservative management of segmental infarction of the greater 
omentum: a case report and review of literature. Case Rep Med. 2010;2010. pii: 765389.

5. Bush P. A case of haemorrhage into the greater omentum. Lancet. 1896; 147: 286.

6. Lardies JM, Abente FC, Napolitano A, Sarotto L, Ferraina P. Primary segmental infarction of the greater omentum: a rare cause of RLQ syndrome: laparoscopic resection. Surg Laparosc Endosc Percutan Tech. 2001 Feb; 11 (1): 60-2.

7. Rao A, Remer EM, Phelan M, Hatem SF. Segmental omental infarction. Emerg Radiol. 2007 Jul; 14 (3): 195-7.

8. Sakellaris G, Stathopoulos E, Kafousi M, Arbiros J, Bitsori M, Charissis G. Primary idiopathic segmental infarction of the greater omentum: two cases of acute abdomen in childhood. J Pediatr Surg. 2004 Aug; 39 (8): 1264-6.

9. Puylaert JB. Right-sided segmental infarction of the omentum: clinical, US, and CT findings. Radiology. 1992 Oct; 185 (1): 169-72.

10.Grattan-Smith JD, Blews DE, Brand T. Omental infarction in pediatric patients: sonographic and CT findings. AJR Am J Roentgenol. 2002 June; 178 (6): 1537-9.

11. Barai KP, Knight BC. Diagnosis and management of idiopathic omental infarction: A case report. Int J Surg Case Rep. 2011; 2 (6): 138- 40.

12. Costi R, Cecchini S, Randone B, Violi V, Roncoroni L, Sarli L. Laparoscopic diagnosis and treatment of primary torsion of the greater omentum. Surg Laparosc Endosc Percutan Tech. 2008 Feb; 18 (1): 102-5. 13. Kavalakat AJ, Varghese CJ. Laparoscopic management of an uncommon cause for right lower quadrant pain: A case report. Cases J. 2008 Sep 19; 1 (1): 164. 